\title{
Correction to: Analytical determination of the turn-to-turn capacitances for the prediction of voltage peaks in a PWM-fed motor winding
}

\author{
Jan Ole Stockbrügger ${ }^{1} \cdot$ Bernd Ponick $^{1}$
}

Published online: 2 November 2021

(c) The Author(s) 2021

\section{Correction to: \\ Electrical Engineering (2020) 102:2381-2388 https://doi.org/10.1007/s00202-020-01036-0}

The article "Analytical determination of the turn-to-turn capacitances for the prediction of voltage peaks in a PWMfed motor winding", written by Jan Ole Stockbrügger and Bernd Ponick, was originally published Online First without Open Access. After publication in volume 102, issue 4, page 2381-2388 the author decided to opt for Open Choice and to make the article an Open Access publication. Therefore, the copyright of the article has been changed to (C) The Author(s) 2021 and the article is forthwith distributed under the terms of the Creative Commons Attribution 4.0 International License, which permits use, sharing, adaptation, distribution and reproduction in any medium or format, as long as you give appropriate credit to the original author(s) and the source, provide a link to the Creative Commons licence, and indicate if changes were made. The images or other third party material in this article are included in the article's Creative Commons licence, unless indicated otherwise in a credit line to the material. If material is not included in the article's Creative Commons licence and your intended use is not permitted by statutory regulation or exceeds the permitted use, you will need to obtain permission directly from the copyright holder. To view a copy of this licence, visit http://creativecommons.org/licenses/by/4.0/.

Open Access This article is licensed under a Creative Commons Attribution 4.0 International License, which permits use, sharing, adaptation, distribution and reproduction in any medium or format, as long as you give appropriate credit to the original author(s) and the source, provide a link to the Creative Commons licence, and indicate if changes were made. The images or other third party material in this article are included in the article's Creative Commons licence, unless indicated otherwise in a credit line to the material. If material is not included in the article's Creative Commons licence and your intended use is not permitted by statutory regulation or exceeds the permitted use, you will need to obtain permission directly from the copyright holder. To view a copy of this licence, visit http://creativecomm ons.org/licenses/by/4.0/.

Publisher's Note Springer Nature remains neutral with regard to jurisdictional claims in published maps and institutional affiliations.
The original article can be found online at https://doi.org/10.1007/s00 202-020-01036-0.

\section{Jan Ole Stockbrügger}

ole.stockbruegger@ial.uni-hannover.de

1 Institute for Drive Systems and Power Electronics, Leibniz University Hannover, Hannover, Germany 